\title{
RAMOS DE ROSAS ROJAS. LAS TRECE ROSAS: MEMORIA AUDIOVISUAL Y GÉNERO
}

\author{
Virginia Guarinos
}

Universidad de Sevilla

La ley de Memoria Histórica de España es aprobada por el Congreso de los Diputados en octubre de 2007 con intención de reconocer y ampliar los derechos de quienes sufrieron persecución y/o violencia durante la Guerra Civil y la dictadura franquista. Desde entonces son muchos los actos sociales y las medidas políticas desarrolladas en los más diversos entornos, desde gubernamentales a municipales, desde asociaciones hasta grupos de amigos. No obstante, a nuestro cine no le ha hecho falta una ley para recordar y plantear una reflexión sobre ambos hechos, el del enfrentamiento bélico y el posterior estado totalitario. Tampoco a nuestra literatura. Desde la llegada de la democracia, en plena transición política, han sido innumerables las publicaciones de novelas y los estrenos de películas que, de un modo u otro, recreaban los años de guerra y postguerra en nuestro país, tanto que hasta casi un subgénero cinematográfico podría denominarse. A veces sobre hechos históricos concretos, otras sobre pequeñas intrahistorias, las películas ambientadas en estas fechas han sabido convertir al cine español en un cine testimonial. No es un fenómeno exclusivo español. El nazismo y el totalitarismo europeo de mitad del siglo XX han dado libros y películas como la famosa La lista de Schindler (S. Spielberg, 1993) o la polémica novela Las benévolas (Johnatan Littell, 2007) además de El niño del pijama de rayas (John Boyne, 2007), best sellers en nuestro país. En todos estos casos se narra con frialdad y detalle los horrores del holocausto nazi. Incluso se han llegado a desarrollar metodologías de trabajo sobre ello, y en el punto que nos atañe de mujeres en el holocausto (Ofer y Weitzman), donde se refiere que la mujer judía pasó, gradual aunque rápidamente, de la humillación pública a la violación para terminar siendo objeto de violencia física y exterminio. ¡Ay! Carmela (Carlos Saura, 1990), La lengua de las mariposas (José Luis Cuerda, 1999), Dragon Rapid (Jaime Camino, 1986), Libertarias (Vicente Aranda,

1 Este artículo va dedicado a los alumnos de la promoción 2003/08 de Comunicación Audiovisual de la Universidad de Sevilla, a quienes les hablé de ello en su ceremonia de graduación como última lección. 
1996), El laberinto del fauno (Guillermo del Toro, 2006), Soldados de Salamina (David Trueba, 2002), La vaquilla (Luis $G^{a}$ Berlanga, 1985) son algunos de los títulos más exitosos en nuestra taquilla que salpican las dos últimas décadas con este tema recurrente que deviene a las pantallas una y otra vez, varios de ellos como adaptaciones fílmicas de relatos literarios.

Con desiguales resultados, tanto en cine como en literatura, este grupo de creaciones sobre nuestra historia reciente ha venido a completarse con un eslabón más en los últimos años: el caso de las trece rosas, las chicas fusiladas el 5 de agosto de 1939 en la tapia del cementerio del Este de Madrid no se sabe por qué, o en todo caso por poco, por haber pertenecido a las Juventudes Socialistas. Estas mujeres, las llamadas Rosas Rojas, han generado un halo romántico y docudramático en torno a ellas y la carga simbólica que conlleva su apelativo, rosas rojas, símbolos de amor y pasión, nada más alejado de la sangre derramada, también roja de forma objetiva y no como mote despectivo a la condición de izquierdistas. Pero éste no ha sido un caso más. De hecho se ha convertido en un fenómeno informativo, artístico y humano que ha generado múltiples productos: literarios, televisivos, cinematográfico, sociales. Una auténtica recuperación de la memoria. Durante mucho tiempo dormido, el suceso ha despertado en los últimos cinco años, pero los testimonios reales aseguran que ya en aquellos momentos la narración oral colaboró a que entre las presas de las cárceles franquistas «la ejecución de las trece rosas — según Gatica- se convirtiera en una suerte de leyenda, en un relato que fue corriendo de boca en boca hasta el punto de que cada presa recién ingresada en Ventas lo hizo suyo y se dedicó a trasmitirlo a su vez»². Desde el primer conocimiento general de la historia hasta el último homenaje ${ }^{3}$, destacamos:

- El libro ensayístico Trece rosas rojas, del periodista Carlos Fonseca4.

- La novela de Jesús Ferrero, Las trece rosas.

- Los documentales: Que mi nombre no se borre de la historia (Verónica Vigil y José María Almela) y Del olvido a la memoria. Presas de Franco (Jorge Montes y Tomás Sequeiros).

- La novela Martina, la rosa número trece, de Ángeles López.

- El poema de Julián Fernández del Pozo, de 2004, titulado Homenaje a las Trece Rosas.

- La película Las trece rosas (2007) de Emilio Martínez-Lázaro.

Además, se ha estrenado el espectáculo flamenco Trece rosas de la compañía de danza Arrieritos en 2005, premiado con el Max de Artes Escénicas a la mejor coreografía y el mejor espectáculo de danza, y una obra de teatro en 2006 por la compañía Delirio ${ }^{5}$. Los documentales sobre ellas han originado ciclos de cine documental en general o sobre presos durante el franquismo. La Fundación Domingo Malagón (PCE) se encarga de organizar homenajes

2 En el artículo de Daniel Gatica Cote, del grupo de investigación Élites, notables y pueblo, «Una cárcel de Posguerra. La Prisión Central de El Puerto de Santa María en 1940: los prisioneros gaditanos». En línea en http://www.cefid.uab.es/files/comuniclll-3.pdf (08/04/08).

3 Último homenaje celebrado al cierre de estas páginas en el cementerio de la Almudena, el sábado 31 de mayo de 2008, promovido por el Ayuntamiento de Madrid.

4 Existe un trabajo anterior de Jacobo García de 1985, reportaje publicado en Historia 16, en bibliografía.

5 El espectáculo de danza fue creado por Héctor González y dirigido por Florencio Campo. La obra teatral fue estrenada en Barcelona, en el Teatro Tantarantana, escrita por Julia Bel, codirigida con Eva Hibernia. 
cada 5 de agosto desde 1988, fecha en la que se destapó una placa en su recuerdo en el sitio donde se produjo el fusilamiento. Y la Fundación Trece Rosas (PSOE) eligió este nombre simbólicamente en relación a los objetivos de la misma: la justicia social e histórica.

De todos ellos, nos centraremos en la novela de Ferrero, la película de Martínez-Lázaro y los dos documentales, no de forma aislada sino aprovechando la transversalidad de dos elementos que atraviesan todas estas producciones, la memoria y el género. La historia contada

- Es una historia real usada como materia poética para crear en novela y cine, pero también para informar en los dos documentales. Se encuentra, por tanto, una diversidad de medios de expresión tan próximos en el tiempo para contar la misma historia que nos conduce a la reflexión de la memoria y su mantenimiento con distintos formatos y diferentes intenciones.

- Es una historia real de mujeres, mujeres comprometidas con su tiempo, que desde una perspectiva de activismo político y feminista nos conduce a la comparación entre las mujeres de la guerra y postguerra y las mujeres del cine vistas desde nuestra perspectiva de hoy.

\section{SOBRE MEMORIA AUDIOVISUAL}

Si tenemos en cuenta que la película ha sido vista por 856.003 espectadores $^{6}$, que del libro de Ferrero se ha vendido un alto número de ejemplares en varios países, que el documental de Vigil y Almela se emitió por TVE y en ciclos de cine y el de las presas de Franco fue seguido por La Sexta, no hay que pensar mucho para darse cuenta de que el caso que tratamos es un ejemplo de difusión entre el público, ya sea lector o espectador. Estamos ante una memoria muy refrescada. Partiremos de la base de que la novela de Ferrero no es comparable, ni como adaptación, con la versión cinematográfica, en tanto que el guión de la película surge del libro de Fonseca. Aún así las similitudes entre ambos discursos con respecto a la memoria son altas, pues ninguno de los dos textos ha pretendido ser documento histórico, ni siquiera recreación. El propio escritor declara en una entrevista (Manrique, 2003) que «las trece rosas se convirtieron en un mito muy pronto. La historia las trataba de una manera neutra y la leyenda las mitificaba. Partí de esas dos fuentes, consciente de que en una novela hay que usar las dos». No obstante, el rigor histórico que no se le ha exigido a la novela, sí ha contado en la valoración de la película, tachada de «irregular y superficial» (Bejarano, 2007). A veces esa distancia de la realidad de Ferrero ha sido un valor añadido hacia la intimidad en su novela. Como afirma Céspedes (2007), «El libro de Ferrero, a pesar de ciertas diferencias importantes respecto del de Fonseca, recurre a ciertas licencias desde el punto de vista histórico, modificando lo realmente acaecido pero sin albergar una intención deformadora de la significación de los hechos reales, sino intentando que la esencia de la historia sea percibida de manera más íntima y a la vez más sólida que a través de un relato más histórico lleno de información y detalles». Esto, que se ha convertido en un factor positivo en la novela, se lo reprochó la crítica a la película, como si en ella hubiera alguna intención distinta a la del relato.

6 Cifra proporcionada por la base de datos del Ministerio. Número de espectadores desde su estreno el 14 de septiembre de 2007. 
Sin duda, se esconde bajo esta desigualdad de tratamiento un problema general con el que cuenta el cine. El cine, al ser realista por naturaleza, levanta un horizonte de expectativas en los receptores, críticos o no, que presupone en él verdad y no sólo verosimilitud. Nada más lejos de su propia naturaleza también, decididamente ficcional. Y, si bien existe el cine documental, es verdad que esta película desde su contexto exterior ha sido planteada como una fabulación, a lo sumo testimonial, y nunca como un documental ${ }^{7}$. El cine documental puede ser un documento, el ficcional será un testimonio de su tiempo, verosímil pero no verdad y no real${ }^{8}$. La ficcionalización, sin embargo, también ha llegado al documental. El propio documental de La Sexta, Del olvido a la memoria. Presas de Franco, de claro matiz fabulado, emplea un tono docudramático que lo aleja del distanciamiento y la focalización externa pedida a la objetividad de una información y nadie le reprocha nada porque adopta una retórica de verdad creíble que hace que el resto de matices pasen desapercibidos al gran público.

El cine documental está de moda desde hace cierto tiempo. El realismo, el hiperrealismo, lo docudramático, también en televisión, son del interés general del público actual. Y cuando se trata de hechos reales, el público y la crítica exigen lo que posiblemente el cine comercial de ficción no puede o no quiere dar. Recordemos que aún así, la historia de las rosas, como comentábamos antes, circuló desde el principio boca a boca, en una transmisión oral que variaba continuamente la historia original. La memoria forma parte de la producción simbólica de la realidad que hace el cine con respecto a la Historia de un país. Y los gobiernos con sus políticas cinematográficas tienen mucho que decir con respecto a los productos fílmicos, de modo que, como afirma Jorge Sala (2007) para el caso argentino", no poco parecido al español, «no se trata de observar si las películas construyen una memoria, sino de cómo ésta se gesta y se transforma en discurso, en otras palabras, cómo es su política de memoria». Como decía Bordieu, los medios, el cine, poseen una autonomía relativa tensionada constantemente por los campos de poder. Por este lado, las constantes referencias de nuestros cineastas a la etapa de guerra civil y postguerra vienen fomentadas por el ambiente general del país y sus vaivenes políticos. Por otro lado, la propia producción documental, también la española, ha experimentado una tendencia a la ficcionalización que hace que ni el cine documental esté tan lejos del cine argumental, ni el ficcional lejos del documento. Son varios los elementos que los recientes documentales desarrollan denotando una «fragilidad del concepto documental», como diría Gómez Tarín (2006): prioridad enunciativa con predominancia del montaje. El boom del cine documental, como también de la telerrealidad, y la hibridación genérica hacen tan legítimas en la política de la memoria audiovisual la ficcionalización del hecho en novela y cine como la objetividad del documental de Almela y Vigil o el docudramatismo del documental de La Sexta. En definitiva, todos sentían la misma prioridad: «Entendimos que era urgente

7 Tampoco la obra de teatro citada anteriormente tenía voluntad histórica, sino ética. Se centra sólo en cuatro de las presas (Dionisia, Julia, Blanca y Martina) y es encauzada por Julia Vellisca, que no fue condenada a muerte sino a prisión por doce años, de los que cumplió seis, al no formar parte de las JSU.

8 Dentro de la clasificación de géneros cinematográficos se plantea un problema a la hora de clasificar determinado tipo de filmes donde se mezclan las etiquetas de cine histórico, cine político, cine testimonial, social, realista, docudramático... (Guarinos 2003). El testimonio como relato de las personas directamente afectadas por los hechos se presenta en el cine documental pero también puede existir un cine ficcional con intención, con voluntad testimonial aunque no aparezcan los afectados.

9 El caso argentino es parecido al español: una política de memoria, una democracia recién nacida y una producción cinematográfica sobre las víctimas y los victimarios. Véase a Fariña y Marrone en bibliografía. 
hacerlo (el documental) porque son pocos los testigos vivos. Si no se recogen ahora sus voces, permanecerán para siempre en el olvido» (Huete, 2005).

Los hechos referidos en los documentos que hemos tratado fueron los siguientes:

- Termina la guerra civil, las Juventudes Socialistas Unificadas en Madrid (tomada el 28 de marzo de 1939) intentan reagruparse y trabajar la resistencia desde la clandestinidad con una merma importante de entre sus miembros debido a las bajas por fallecimiento o por exilio.

- El aparato represor del nuevo estado dictatorial investiga e intenta localizar a los jóvenes afiliados para encarcelarlos o ejecutarlos. Muchos de ellos fueron arrestados entre marzo y mayo de 1939.

- Se produce el atentado a Isaac Gabaldón, tiroteado junto a su hija y su chófer en julio de 1939. Era el responsable del archivo de masones y comunistas. Había detectado un caso de corrupción entre las filas del régimen, al darse cuenta de que tres militares se enriquecieron cobrando favores a «los rojos» por escapar. Parece que estos tres militares pudieron ser los inductores de su asesinato.

- No obstante, como escarmiento y acto ejemplificador, el Régimen decide ejecutar como responsables a los jóvenes de la JSU (cuarenta y tres hombres y trece mujeres), encarcelados ya cuando se produjo el atentado.

- El fusilamiento se produjo dos días después del juicio, el 5 de agosto del 39 en la tapia del cementerio del Este, sin que las cartas de petición de indulto hubieran sido tramitadas.

Todos estos hechos quedan claros en la película, no tanto en la novela, bien es cierto que, al tratarse ambos de historias corales, dicha coralidad influye a la hora de profundizar poco en cada una de las protagonistas, los antecedentes y la vida en prisión. La acusación de poco trágica que se suele proferir sobre la película es inevitable, porque inevitable es la comparación con la realidad de la galería de penadas o con el fusilamiento (que no se ve) al tratarse de una película «basada en hechos reales». El deseo de ver más, la pulsión escópica del espectador actual es muy alta, acostumbrado como está a lo que las televisiones le ofrecen en los realities y más aún al tratarse de un hecho histórico. En cualquier caso, el hacinamiento en la cárcel de Ventas (para cuatrocientas cincuenta reclusas y ocupación real de cuatro mil presas), las torturas, los interrogatorios, los escasos ratos de alegría y de risas de las mujeres, su activismo político quedan reflejados fielmente tanto en la novela como en la película. José Pena Brea, de veintiún años, era el Secretario General de la JSU y bajo tortura en la comisaría de Vallecas, delató a muchos de sus compañeros, detenidos y fuente de nuevas delaciones, entre ellas las de las trece jóvenes. La delación llegó a ser una «cura de salud» para muchos, intentando así congraciarse con el Régimen y llegando a delatar a los propios familiares. Tras ella venía la detención y la tortura: anillas eléctricas, falta de sueño, corrientes en pechos, en muñecas, en los dedos de pies y manos, torturas psicológicas, humillaciones como el rapado del cabello en cabeza y cejas, violaciones... La cárcel de mujeres de las Ventas, de 1933, paradójicamente fue diseñada por otra mujer, Victoria Kent, pero con la intención de servir de centro de reinserción de reclusas, aunque terminara siendo un lugar inhóspito donde había mujeres, algunas con sus hijos, durmiendo incluso en retretes, comiendo una vez al día, compartiendo parásitos y enfermedades contagiosas. Toda esta crueldad extrema es sugerida en 
la película, también en el libro, aunque la película ahorra al espectador la visión sangrienta del fusilamiento, más detallado en la novela, al estilo de la tragedia griega.

\section{SOBRE GÉNERO Y ACTIVISMO POLÍTICO}

La situación de la mujer en España hasta llegar a la que goza hoy ha pasado por muy diversos estadios, pero hay uno de mayor regresión y desfavorecimiento, el de la dictadura franquista. Y esto sucede en uno de los órdenes de la vida de la mujer, su situación laboral, profesional y política. La escasez de la presencia femenina en la política previa a la II República corre paralela a su discriminación en el primer movimiento obrero (Gutiérrez Sánchez, 2003). Las cigarreras, por ejemplo, fueron un colectivo en este sentido bastante notable en reivindicaciones laborales aunque no bien vistas. De las mujeres trabajadoras muy pocas eran afiliadas y las que lo hacían recurrían a sindicatos católicos. Al fin y al cabo, a principios de siglo XX la incorporación de la mujer al trabajo era considerada desleal competencia al varón. Los marcos legales discriminaban a una mujer en una relación de subordinación al varón también desde el punto de vista económico, aunque, eso sí, fueron iguales para ser asesinadas. La mujer como ángel sumiso del hogar era el objetivo del franquismo, una mujer católica y decente amparo de su marido y de sus hijos, fuente de donde prolongar la raza. Por ello mismo, la mujer de izquierdas o, sencillamente republicana, en una clara equivocación que igualaba republicano a izquierdista y ateo, era la simiente de las generaciones del otro bando que había que aniquilar.

La representación de la película de Martínez-Lázaro es rica en este sentido, en tanto que se retrotrae a los momentos anteriores a las detenciones y de ese modo se visualiza la dedicación profesional y política de las muchachas cuando podían hacerlo, mientras estaban en la calle. La lucha política queda algo diluida porque es compartida con las relaciones personales familiares y sentimentales, que al fin y al cabo también ocupaban parte del tiempo de sus vidas. Sobre todo son dos las mujeres más activas, Carmen y Virtudes. Sus tareas de beneficencia, en comedores, también quedan reflejadas en el texto fílmico. Lo cierto es que no se trata más que de reflejar la realidad de la mujer de la República y de la mujer republicana durante la guerra y postguerra. Mujeres señaladas por su actividad política y social hubo en los dos bandos, pero no todas fueron Dolores Ibárruri, La Pasionaria, ni Pilar Primo de Rivera. Otras muchas, como las chicas-rosas, fueron mujeres anónimas que en sus domicilios escondían a hombres y mujeres en busca y captura o que ayudaban a huir o a alimentar. En un peldaño intermedio están estas mujeres que desde su afiliación a la JSU, con cargos o sin ellos, participaron en el Socorro Rojo, servicio social de la Internacional Comunista, organizado en 1922 y que, al estilo de la Cruz Roja, daba apoyo humanitario y material al ámbito izquierdista, dirigido por mujeres. En casa, en los sindicatos, en los trabajos, en la política profesional, en la guerrilla, en los alzamientos, siempre ha habido mujeres, sin duda en menor número que los hombres y, por su puesto, mucho menos visualizadas que ellos. Muy pocas pasaron a la Historia. Clara Campoamor y el sufragio, en el activismo político, Victoria Kent y Margarita Nelken, de tres partidos diferentes en nuestra república son algunos de los nombres más importantes. Las de menos renombre también han merecido la utilización de su nombre y sus vidas a veces noveladas y otras no. Prueba de ello son los títulos de libros sobre mujeres antifranquistas: Rosario Dinamitera, una mujer en el frente de Carlos Fonseca, sobre Rosario Sánchez Mora, desde los diecisiete años integrada en una sección de dinamiteros, o la novela de Dulce Chacón, La 
voz dormida. Los documentos audiovisuales de la época, las fotografías, los textos escritos, los carteles reflejan una representación de la mujer en la II República que se acerca a lo que Santiago Carrillo afirma en el documental Que mi nombre no se borre de la Historia. La propia presencia de la mujer en la cartelería de propaganda en el bando republicano es un síntoma de la presencia, del activismo político de la mujer de izquierdas. La mujer en la época de la guerra civil era analfabeta, no trabajadora, a pesar de que los primeros movimientos feministas más o menos organizados empezaron a darse en España en los años veinte, muy tímidamente, y con los objetivos de acceder a la educación y a la vida laboral. Durante la República el sufragismo, las secciones femeninas de los partidos políticos, el divorcio, el reconocimiento del matrimonio civil, la primera mujer ministra (Federica Montseny, anarquista, entre noviembre de 1936 y mayo del 37) conformaban un panorama de logros femeninos parecidos a los de hoy. Las milicianas eran mujeres jóvenes, con vínculos políticos, familiares e incluso afectivos con compañeros; repetimos, compañeros, no superiores. Las propias declaraciones de los supervivientes de las cárceles que aparecen en los documentales referidos nunca hablan como mujeres, hablan como militantes, de igual a igual con sus compañeros hombres. Sus motivaciones para la conciencia social y política se basaron en el rechazo al fascismo y la defensa de los derechos adquiridos durante la II República, como ciudadanos y como mujeres. La imagen de la mujer en la película y en la novela no se corresponde con una imagen romántica de la heroína combatiente; no es un estereotipo, es real. Mujeres que, como en los carteles y fotos, no estaban subordinadas, vestían monos de mecánico y ejercían de ello al mismo nivel que de costureras, portaban fusiles y, aún más, sabían usarlos. Entre ellas había obreras, profesionales o amas de casa en la retaguardia haciendo labores sociales de apoyo. Muchas estaban agrupadas, hasta sesenta mil afiliadas en las distintas asociaciones. Una de las más importantes fue la AMA, Asociación de Mujeres Antifascistas, comunistas, socialistas y republicanas, incluidas las católicas, presididas por Encarnación Fuyola. Además de ésta, otras dos asociaciones sumaban a la lucha política la reivindicación feminista: la anarquista Mujeres Libres y el Secretariado Femenino del POUM. La movilización de la mujer republicana fue alta: se integra en la guerra, se la llama para la industria, con un índice de igualdad bastante claro. El nacionalsocialismo también contó con la Sección Femenina de Falange creada en 1934. Pero el rol de la mujer es distinto a los anteriores. La mujer es el complemento del hombre. Se dedicaron a la asistencia de heridos o familias de los desaparecidos en combate, a la protección de madres y huérfanos y de ancianos, a los talleres de costura de ropa para soldados, encabezadas por Pilar Primo de Rivera. En palabras de Fernández Rodríguez (2007), las mujeres republicanas, aunque vivieran en una sociedad como la franquista, anclada en el pasado, se negaron al papel que les habían impuesto de madres y esposas dedicadas exclusivamente a sus maridos.

Así lo ejercían las Trece Rosas, siete de ellas menores (la mayoría de edad estaba fijada en los veintiún años), quienes vivieron el recorte por lo sano de las libertades e igualdades para la mujer, situación que se ha recuperado con la democracia y otras acciones mundiales, como la IV Conferencia mundial sobre las mujeres. Celebrada en Pekín (1995), ha reivindicado el empoderamiento y las políticas de igualdad de los gobiernos, incluyendo a la mujer en el proceso de decisión ${ }^{10}$.

10 La Conferencia de Pekín y las de seguimiento de Nueva York en 2000 y 2005 han marcado hitos hacia la igualdad. Véase Pilar Giménez Armentia, «Un estudio sobre la IV conferencia mundial sobre las mujeres», Comunicación y hombre, n³, 2007, pp. 81-94. 
Carlos Fonseca tuvo la intención de preparar una obra con exhaustividad y rigor histórico, accediendo al sumario y entrevistándose con supervivientes. Igualmente lo hicieron Verónica Vigil y José María Almela en su documental. Jesús Ferrero declaraba en una entrevista (Manrique, 2003) que no se acercó a ellas para recuperar una memoria perdida sino que «el interés era totalmente literario. Me enamoré del concepto 'trece rosas' en cuanto lo vi. Tuve la impresión de que ahí me podía reencontrar con la tragedia griega sin necesidad de irme a Grecia». De la misma manera, Martínez-Lázaro deja bien claro en la web de la película sus intenciones:

¿Deberá nuestra historia ser primordialmente la denuncia de un hecho histórico, de un terrible, arbitrario y cruel acto de venganza ejercido por unos vencedores arrogantes sobre trece muchachas inocentes, o más bien deberemos esperar que, en todo caso, la denuncia caiga por su peso al reinventar y hacer vivir en la pantalla los últimos días de las chicas, con su juventud recién estrenada, sus proyectos e ilusiones, sus primeros amores, su idealismo combativo y su valor cívico y personal? Dicho de otra manera, ¿vamos a centrar la película en los hechos históricos o en los personajes? Sin duda, la segunda opción es la buena. En primer lugar porque la película es un continuo de una duración limitada. La complejidad del suceso y todas sus derivaciones son más propias para ser tratadas por un investigador en forma escrita o, en todo caso, en un documental fílmico. La película se servirá de los hechos reales como una ayuda para comprender algo que, si no hubiera pasado, nos resultaría difícil imaginar. Por mucho que nos esforzáramos, en dos horas es imposible hablar de todo lo que rodeó aquel suceso. Pero sobre todo porque el campo de acción del cine es el de los sentimientos del espectador, mucho más que el de su ilustración.

En la propia web de la película se puede profundizar, encontrando allí correspondencias con personas reales de los personajes de las películas, las cartas y los hechos históricos como fueron, sin ninguna intencionalidad de ocultar la filosofía de la película ni el origen real. Y aunque se centra en cinco de los personajes: Carmen y Virtudes, Blanca, Julia y Adelina, también la novela trabaja unas más que otras. Una tabla comparativa de las muchachas en la realidad, la novela y la película destacaría los siguientes datos.

\begin{tabular}{|l|l|l|l|}
\hline Rosa & Historia & Novela & Película \\
\hline $\begin{array}{l}\text { Carmen Barrero, } \\
\text { "Marina" }\end{array}$ & $\begin{array}{l}\text { Modista, 20 años. Militante del PCE y } \\
\text { responsable femenina del partido en } \\
\text { Madrid tras la guerra. Detenida el 16 de } \\
\text { mayo del 39. }\end{array}$ & $\begin{array}{l}\text { Silenciosa. Inte- } \\
\text { rrogada por El } \\
\text { Pálido. }\end{array}$ & \\
\hline Martina Barroso & $\begin{array}{l}\text { Modista, 24 años. Empieza a participar } \\
\text { en la JSU tras la guerra. Buscaba armas } \\
\text { y municiones. }\end{array}$ & $\begin{array}{l}\text { Sueña con un } \\
\text { amor romántico. } \\
\text { Pecosa, delgada } \\
\text { y pálida. }\end{array}$ & \\
\hline Blanca Brisac & $\begin{array}{l}\text { Pianista, 29 años. Tenía un hijo. No mili- } \\
\text { taba. Era católica y votante de derechas. } \\
\text { Detenida por la relación de su marido } \\
\text { con un músico del PCE. La carta que es- } \\
\text { cribió a su hijo el 5 de agosto fue entre- } \\
\text { gada a su familia 16 años después. }\end{array}$ & $\begin{array}{l}\text { violinista. Trenzas } \\
\text { largas que le cor- } \\
\text { taron. Interroga- } \\
\text { torios suaves. }\end{array}$ & $\begin{array}{l}\text { Católica, refina- } \\
\text { da, artista, cariño- } \\
\text { sa y alegre. Dice } \\
\text { explícitamente } \\
\text { que es votante } \\
\text { de derechas. }\end{array}$ \\
\hline
\end{tabular}




\begin{tabular}{|c|c|c|c|}
\hline Pilar Bueno & $\begin{array}{l}\text { Modista, } 27 \text { años. Afiliada al PCE al co- } \\
\text { mienzo de la guerra. Voluntaria en casa } \\
\text { cuna. Secretaria de organización de Ra- } \\
\text { dio Norte. Encargada de reorganizar el } \\
\text { partido tras la guerra. Detenida el } 16 \text { de } \\
\text { mayo. }\end{array}$ & $\begin{array}{l}\text { Irónica. Maltra- } \\
\text { tada a tortazos. } \\
\text { Compartía celda } \\
\text { con Joaquina. }\end{array}$ & \\
\hline Julia Conesa & $\begin{array}{l}\text { Modista, } 19 \text { años. Afiliada a la JSU por } \\
\text { motivos deportivos donde se ocupaba } \\
\text { de monitorizar. Cobradora de tranvía. }\end{array}$ & $\begin{array}{l}\text { Enfermera. La } \\
\text { detiene El Pálido } \\
\text { en su casa. }\end{array}$ & $\begin{array}{l}\text { Colabora en un } \\
\text { comedor. Es co- } \\
\text { bradora de tran- } \\
\text { vía. Conoce a } \\
\text { un militar que se } \\
\text { hace novio de } \\
\text { ella. }\end{array}$ \\
\hline $\begin{array}{l}\text { Adelina García } \\
\text { Casillas, "La Mu- } \\
\text { lata" }\end{array}$ & $\begin{array}{l}19 \text { años. Militante, hija de guardia civil. } \\
\text { Ingresa en prisión el } 18 \text { de mayo. Sólo } \\
\text { iban a interrogarla de rutinariamente. }\end{array}$ & $\begin{array}{l}\text { Avelina. Novio } \\
\text { enfermizo en } \\
\text { el pueblo en el } \\
\text { que se refugia- } \\
\text { ba. Pertenecía al } \\
\text { Socorro Rojo. De } \\
\text { una paliza, que- } \\
\text { da con un ojo } \\
\text { morado, referido } \\
\text { por Joaquina. }\end{array}$ & $\begin{array}{l}\text { Colabora en el } \\
\text { comedor y es } \\
\text { amiga de Julia. } \\
\text { Se la llevan al } \\
\text { pueblo, donde } \\
\text { tiene un novio } \\
\text { que combatió en } \\
\text { la zona nacional. }\end{array}$ \\
\hline Elena Gil Olaya & $\begin{array}{l}20 \text { años. Ingresa en JSU en el } 37 \text { y al fi- } \\
\text { nal de la guerra colaboraba en el grupo } \\
\text { de Chamartín. }\end{array}$ & $\begin{array}{l}\text { Estaba ciega. } \\
\text { No había hecho } \\
\text { nada, sólo tenía } \\
\text { amigas en el So- } \\
\text { corro Rojo. }\end{array}$ & \\
\hline $\begin{array}{l}\text { Virtudes González } \\
\text { García }\end{array}$ & $\begin{array}{l}\text { Modista, } 18 \text { años. Amiga de Carmen } \\
\text { Cuesta (15 años y superviviente de la } \\
\text { prisión de Ventas, también militante). } \\
\text { Detenida el } 16 \text { de mayo. Y delatada por } \\
\text { un compañero bajo tortura. }\end{array}$ & $\begin{array}{l}\text { Pertenece al So- } \\
\text { corro Rojo. Refe- } \\
\text { rencias a su rela- } \\
\text { ción sentimental } \\
\text { con Vicente. Se } \\
\text { escondía cons- } \\
\text { ciente de que } \\
\text { iban a por ella. } \\
\text { Larga cabellera y } \\
\text { ojos negros. }\end{array}$ & $\begin{array}{l}\text { Muy activa. Niñe- } \\
\text { ra tras la guerra } \\
\text { para familias fas- } \\
\text { cistas. Aterroriza- } \\
\text { da ante el hecho } \\
\text { de morir. }\end{array}$ \\
\hline $\begin{array}{l}\text { Ana López Galle- } \\
\text { go }\end{array}$ & $\begin{array}{l}\text { Modista, } 21 \text { años. Afiliada y secretaria } \\
\text { de Radio Chamartín en la guerra. De- } \\
\text { tenida el } 16 \text { de mayo. No murió en la } \\
\text { primera descarga. }\end{array}$ & $\begin{array}{l}\text { Pertenece al So- } \\
\text { corro Rojo. La } \\
\text { más guapa, le } \\
\text { gusta a Roux, y } \\
\text { está apunto de } \\
\text { serviolada por El } \\
\text { Pálido. Su novio } \\
\text { Francisco se va } \\
\text { a Alicante para } \\
\text { exiliarse. Espiga- } \\
\text { da y rubia. }\end{array}$ & \\
\hline
\end{tabular}




\begin{tabular}{|c|c|c|}
\hline $\begin{array}{l}\text { Joaquina López } \\
\text { Laffite }\end{array}$ & $\begin{array}{l}23 \text { años. Afiliada desde el 36. Secretaría } \\
\text { femenina del comité provincial. Denun- } \\
\text { ciada por Severino Rodríguez, número } \\
\text { dos de las JSU. Detenida el } 18 \text { de abril. }\end{array}$ & $\begin{array}{l}\text { Conocía a Aveli- } \\
\text { na. Tenía miedo. } \\
\text { La interroga El } \\
\text { Pálido. Muy de- } \\
\text { cidida. Ojos ne- } \\
\text { gros. No se sabe } \\
\text { de su actividad } \\
\text { ni su edad. }\end{array}$ \\
\hline $\begin{array}{l}\text { Dionisia Manza- } \\
\text { nero }\end{array}$ & $\begin{array}{l}\text { Modista, } 20 \text { años. Afiliada desde el } 38 . \\
\text { Era enlace entre dirigentes comunistas } \\
\text { de Madrid. Detenida el } 16 \text { de mayo. }\end{array}$ & $\begin{array}{l}\text { Ya encarcelada. } \\
\text { Borda. }\end{array}$ \\
\hline $\begin{array}{l}\text { Victoria Muñoz } \\
\text { García }\end{array}$ & $\begin{array}{l}18 \text { años. Afiliada desde los 15. llegó el } 6 \\
\text { de junio a la cárcel. }\end{array}$ & $\begin{array}{l}\text { Cumple los } 18 \\
\text { años en la cárcel. } \\
\text { Conocía a Ana. } \\
\text { Padecía insom- } \\
\text { nio. Un hermano } \\
\text { muerto ya y otro } \\
\text { preso. }\end{array}$ \\
\hline $\begin{array}{l}\text { Luisa Rodríguez } \\
\text { de Lafuente }\end{array}$ & $\begin{array}{l}\text { Sastra, } 18 \text { años. Entra en JSU en el } 37 \\
\text { sin cargo. En abril entró en Ventas. Fue } \\
\text { la primera de las trece en llegar a pri- } \\
\text { sión. }\end{array}$ & $\begin{array}{l}\text { La muda. Des- } \\
\text { de que la detu- } \\
\text { vieron se negó } \\
\text { a hablar y sólo } \\
\text { volvió a hacerlo } \\
\text { cuando estaba } \\
\text { en capilla. }\end{array}$ \\
\hline
\end{tabular}

Los cuatro textos son complementarios y cada uno aporta algo valioso a la recuperación de la memoria de este suceso.

La novela desarrolla una buena estructura capitular organizada en torno al nombre de cada una de ellas -lo cual ayuda a identificarlas, pues son muchas como personajes principales- agrupada en cuatro partes: detenciones, llegada a prisión, vida en ella y fusilamiento. La presencia de la mujer es aún más destacada por la aparición de madres, hermanas y novias de los personajes centrales. Cuenta con el valor añadido de la aparición y descripción de otras mujeres, las mujeres del régimen y las religiosas, su crueldad y poca piedad: Verónica Carranza, funcionaria directora, que no envía las peticiones de indulto; Zulema, funcionaria enamorada de Virtudes. En general, hay un elemento temático que recorre todo el texto: la locura. Muchas de las reclusas se refieren a lo que están viviendo como una locura. Damián, el personaje que abre la novela, con un inicio muy cinematográfico, antiguo actor ingresado en un psiquiátrico, piensa que lo que ve por la ventana no es la realidad sino una película bélica. También hay hombres, en menor medida y protagonismo: El Ruso, Julián, miliciano hermano de Damián, que escondiéndose permanentemente es, al final, tiroteado. Y los hombres del aparato represor que atraviesan todos los capítulos con sus incoherencias, sus perversiones y maldades: Roux, El Pálido (Héctor) y Cardinal, los que las detuvieron, torturaron, interrogaron y seleccionaron arbitrariamente para formar parte de ese grupo después de una comida en el Ritz: Luisa, la primera por no haber hablado, Avelina por ser la más conocida en la cárcel, igual que Julia entre las menores. El estamento religioso también resulta extremadamente cruel y dispone el material para demostrar el anticlericalismo de las reclusas, más acusado en Dionisia: Don Valeriano, el cura de la cárcel, María Anselma, la monja que se recrea ante 
las muchachas moribundas. Algunos momentos quedan grabados en la retina del lector que en realidad sólo ha visto palabras sobre el papel: el perro Muma que se despide de ellas, la madre de Virtudes tras el camión, el relato del fusilamiento y los tiros de gracia cuando dos de ellas no mueren a la primera, la incertidumbre de Avelina al no saber si su padre estaba o no en el pelotón de fusilamiento... Termina el libro en el año 1975, también con mujeres madrileñas, pero esta vez, mujeres jóvenes, felices, demócratas y libres.

La película plantea con fidelidad el ambiente general de la toma de Madrid, incluso con algunas imágenes parecidas a las reales que se pueden ver en documentales, como la retirada de sacos terreros de la estatua de Cibeles en Madrid. Las delaciones entre familiares, vecinos y amigos, las torturas a hombres y mujeres, las vejaciones y humillaciones, las otras vidas distintas a las políticas, las relaciones familiares y sentimentales de las muchachas, sus labores humanitarias. Aunque ha evitado el exceso de visualización de otros elementos: los rapados de cabezas, las violaciones, el fusilamiento, los cuerpos muertos. Centrarse en sólo cinco de ellas concentra más el hilo argumental, o mejor dicho en cuatro, en tanto que Carmen, La Peque, no fue una de las trece ajusticiadas. La elección de las chicas es un acierto, ya que Blanca no era militante, era votante de derechas y católica y aún así fue fusilada, lo cual demuestra la arbitrariedad manifiesta del hecho. Por otro lado, la selección de Carmen, una superviviente, supone también dejar una puerta abierta a la esperanza. La recreación del asesinato de Gabaldón casi al final de la película, cuando ya están todas encarceladas, deja claro que no pudieron ser ellas. La presencia del compañero, Teo, que accede a colaborar con delaciones cuando sabe que sus padres han sido detenidos, la paralización por miedo de Virtudes, una de las más activas (su novio la llama «líder incombustible»), el modo en que obligan a cantar el Cara al sol a una pareja de ancianos... son momentos del filme dirigidos directamente el sentimiento. Aunque quizás hay otros desconcertantes, como ver llorar a la directora de la prisión cuando las chicas salen de la cárcel para el cementerio, trayecto que harán cantando el himno de la Joven Guardia. En cualquier caso, los personajes del bando represor quedan desdibujados, tanto funcionarias como policías. Es escalofriante la imagen final de los niños jugando al pelotón de fusilamiento y Enrique, hijo de Blanca, pasando entre ellos mientras lee la última carta de su madre, precisamente fusilada.

El documental de Vigil y Almela es un trabajo bien documentado, exhaustivo y con todas las características de su género. Extenso y con un amplio fondo de imágenes fotográficas y cinematográficas de la época, alterna la intervención del narrador heterodiegético, masculino, distanciado con los testimonios de mujeres que estuvieron encarceladas y el de Carmen, La Peque, superviviente, además de contar con la ratificación de una profesora especialista y del dirigente Santiago Carrillo. Su objetivo es la verdad, no la verosimilitud. De gran sobriedad en la realización, no sólo los testimonios directos son importantes, también las imágenes que demuestran la actividad de las mujeres en la guerra y tras ella: mujeres cosiendo en talleres, cocinando, atendiendo comedores, en enfermerías, pero también desfilando, manejando armas, trabajando como mecánicos de coches, en manifestaciones, portando pancartas en imágenes de archivo en blanco y negro. Concha Carretero, Maruja Borrell, Nieves Torres, Carmen Cuesta, la pequeña amiga de las rosas, dejan claras sus condiciones de mujeres por la libertad, comprometidas y con sentimiento profundo de sus convicciones, considerándose iguales a sus compañeros hombres. El toque docudramático viene dado por algunos efectos sonoros, la música, los testimonios llorosos de alguna de las encarceladas, aunque mínimo en comparación con el documental de La Sexta. Los relatos sobre la vida en la cárcel son escalo- 
friantes: el hacinamiento, la «comida», la suciedad, las torturas, pero también la escuela ideológica y cultural que era, los momentos de rebeldía, los de diversión, los de cantares jocosos, en los que ellas mismas adivinaban sus destinos: «Los soldaditos de Franco aprovechan la ocasión para tirarnos tiritos a las menores de la prisión».

El documental de La Sexta, de modo más impresionista, de menor duración y menor documentación, se centra en las presas en general y de modo anecdótico se nombra a las trece rosas. La importancia de este trabajo es que es signo de nuestro tiempo en cuanto a la hibridación genérica. Intentando ser un documental objetivo consigue altas cotas de docudramatismo. La narradora, externa y también mujer, interviene poco para encauzar y dirigir la información. Se deja a las voces de las protagonistas esta tarea. Esta narradora en su entonación y en su léxico demuestra una implicación emocional superior a la anterior, próxima a la subjetividad. A ello habría que añadir la estructura de mantenimiento de la intriga, para fomentar el deseo de visión de los espectadores, un recurso muy ficcional. Además existen reconstrucciones, puestas en escenas que acompañan los parlamentos testimoniales en sustitución de imágenes de archivo: suelos sucios con mechones morenos cortados cuando se habla de rapar a mujeres, un fusilamiento reconstruido, imágenes de cárceles, de salas de tortura, suelos y ropas manchadas de sangre y una mujer mayor escribiendo unas cuartillas y mirando unas fotos en un despacho. La cuidada iluminación, la selección de escenarios para dichas ambientaciones recreadas demuestran un acercamiento a la ficcionalización. Aunque repiten mujeres del otro documental que hemos referido, éste se basa en Tomasa Cuevas, una expresa condenada a treinta años y que coincidió con muchas camaradas, que se dedicó a recopilar voces grabadas que dieron como fruto una publicación con trescientos testimonios, recuperados por Jorge Montes Salguero, profesor director histórico del documental.

Todos los textos referidos, más los demás que no han tenido cabida aquí, han contribuido al deseo de Julia Conesa: "Que mi nombre no se borre de la Historia». Pero a estas alturas de nuestra Historia, no estaría de más no olvidar las palabras de Blanca Brisac a su hijo: «No guardes rencor a los que dieron muerte a tu madre». Ambos deseos son compatibles.

\section{BIBLIOGRAFÍA}

BARRANQUERO, Encarnación, EIROA, Matilde \& NAVARRO, Paloma (1994), Mujer, cárcel y franquismo. La prisión provincial de Málaga (1937-1945), Málaga, edición del autor.

BEJARANO,Fernando(2007), «Las13rosas», Cineparaleer.Enlíneaenhttp://80.34.38.142:8080/ cineparaleer/index.php?option $=$ com_content\&task=view\&id=375\&ltemid $=28$ (14/05/08).

BOYNE, John (2007), El niño con el pijama de rayas, Barcelona, Salamandra.

CAPARRÓS LERA, José Mª (1995), «El cine como documento histórico», en PAZ REBOLLO, María Antonia \& MONTERO, Julio (eds.), Historia y cine: realidad, ficción y propaganda, Madrid, Editorial Complutense, pp.35-46.

CÉSPEDES, Jaime (2007), "Las trece rosas de la guerra civil vistas por el novelista Jesús Ferrero y el periodista Carlos Fonseca», en Tonos. Revista electrónica de estudios filológicos, $n^{\circ}$ 14. En línea en http://www.um.es/tonosdigital/znum14/secciones/estudios-4-13rosas. htm (08/03/08).

CUEVAS, Tomasa (1985), Cárcel de mujeres. 1939-1945, Barcelona, Sirocco Books. 
DI FEBO, Giuliana (1979), Resistencia y movimiento de mujeres en España. 1936-1976, Barcelona, Icaria.

DOÑA, Juana (1978), Desde la noche y la niebla (Mujeres en las cárceles franquistas), Madrid, Ediciones de la Torre.

FARIÑA, Mabel \& MARRONE, Irene (2007), «Más allá de héroes y villanos. Derechos humanos, dictadura y memoria en el cine», en Afuera. Estudios de crítica cultural, n 3, 2007. En línea en http://www.revistaafuera.com/pagina.php?seccion=Articulos\&page=03.Articulos.Marrone.Farina.htm\&idautor $=67, \% 2068$.

FERNÁNDEZ RODRÍGUEZ, Carlos (2007), La lucha es tu vida. Retrato de nueve mujeres combatientes republicanas, Madrid, Fundación Domingo Malagón.

FERRERO, Jesús (2003), Las trece rosas, Madrid, Siruela.

FONSECA, Carlos (2004), Trece rosas rojas: La historia más conmovedora de la guerra civil, Madrid, Temas de Hoy.

GARCÍA BLANCO-CICERÓN, Jacob (1985), «Las trece rosas», en Historia 16, nº 106.

GÓMEZ TARÍN, Francisco Javier (2006), «La realidad como construcción o la fragilidad del concepto documental», en Actas del II Congreso Internacional sobre el cine europeo contemporáneo (CICEC), Barcelona, Univ. Pompeu Fabra, 2006.

GUARINOS, Virginia (2003), «Cine testimonial», en VVAA, Literatura y cine, Jerez de la Frontera, Fundación Caballero Bonald.

GUTIÉRREZ SÁNCHEZ, Mercedes (2003), «La discriminación femenina en el primer movimiento obrero», en ADAM MUÑOZ, Ma Dolores y PORRO HERRERA, Ma José (eds.), Violencia y género, Córdoba, Universidad de Córdoba, pp. 25-34.

HUETE, Lola (2005), «La corta vida de trece rosas», El País, 11-XII- 2005.

LITTELL, Johnatan (2007), Las benévolas, Barcelona, RBA.

LÓPEZ, Ángeles (2006), Martina, la rosa número 13, Barcelona, Seix Barral.

MANRIQUE, Winston (2003), «El olvido en España ha sido aterrador. Entrevista a Jesús Ferrero», El País, 15-III-2003.

MESSEGUER, Enrique (2007), «Trece rosas: La guerra de la postguerra», en Clío. Revista de Historia, $n^{\circ} 72$, pp. 90-97.

OFER, Dalia \& WEITZMAN, Lenore (2004), Mujeres en el Holocausto. Fundamentos teóricos para un análisis de género del Holocausto, México, Plaza \& Valdés.

PAZ REBOLLO, Ma Antonia \& MONTERO, Julio (eds.) (1995), Historia y cine: realidad, ficción y propaganda, Madrid, Editorial Complutense.

ROJAS FRIEND, Antonio \& NÚÑ̃EZ, Mirta (1993), «Las trece rosas: Nuevas revelaciones sobre su ejecución», en Historia 16, n 205, pp. 21-25.

ROMEU, Fernanda (2002), El silencio roto. Mujeres contra el franquismo, Barcelona, El viejo topo.

ROSENSTONE, Robert, «La historia en la pantalla», en PAZ REBOLLO, Mª Antonia \& MONTERO, Julio (1995:13-34).

SALA, Jorge (2007), "Políticas de la memoria y política cultural en el cine de la democracia», en Afuera. Estudios de crítica cultural, n 2, mayo. En línea en http://www.revistaafuera. $\mathrm{com} /$ pagina. php? seccion=Articulos\&page=02.Articulos.Jorge. Sala.htm\&idautor $=35$.

VINYES, Ricard, (2001), «Nada os pertenece. Las presas de Barcelona. 1939-1945», en Revista de Historia Social, $n^{\circ} 39$, pp. 49-66.

VVAA (2008), La recuperación de la memoria histórica. Una perspectiva transversal desde las ciencias sociales, Sevilla, Centro de Estudios Andaluces. 